\title{
Improving EFL Learners' Critical Thinking Skills in Argumentative Writing
}

\author{
Nabila Nejmaoui ${ }^{1}$ \\ ${ }^{1}$ Faculty of Letters and Human Sciences, Mohammed V University, Rabat, Morocco \\ Correspondence: Nabila Nejmaoui, Faculty of Letters and Human Sciences, Mohammed V University, Rabat, \\ Morocco.
}

Received: October 28, 2018

Accepted: December 11, 2018 Online Published: December 14, 2018

doi: $10.5539 /$ elt.v12n1p98

URL: https://doi.org/10.5539/elt.v12n1p98

\begin{abstract}
In the $21^{\text {st }}$ century where information has become easily available and accessible, education has shifted its attention to teaching students how to process and think critically about the information they receive. Welcoming the changes that education constantly witnesses, the field of English Language Teaching (ELT) has embraced the integration of critical thinking. Accordingly, the present paper aims to explore the effect, if any, of integrating critical thinking on learners' use of critical thinking skills in argumentative writing. To this end, an experimental study was conducted; 36 Moroccan EFL learners from the department of English were divided evenly into an experimental group and a control group. While the participants in the experimental group were taught writing with critical thinking skills, the others were taught writing with no reference to these skills. The participants in both groups took a pre-test and posttest to evaluate the development of their use of critical thinking skills in argumentative writing. The data which has been quantitatively analyzed indicates that the experimental group significantly outperformed the control group. The students' ability to use more credible evidence, address alternative arguments, support conclusions, and maintain the logical flow of ideas in their essays did not reach a mastery level in the posttest, yet the average level they reached is reassuring in view of the short time of the training they had. An integration of CT for longer periods may bring forth encouraging outcomes.
\end{abstract}

Keywords: writing, critical thinking, ELT, higher education, argumentation

\section{Introduction}

Higher education is a stage in students' life where they are expected to achieve two major goals by the end of their education. They should be able to (i) obtain sufficient knowledge about a discipline or a subject matter, and most importantly, (ii) think critically about the knowledge they have obtained and other topics or issues they face in their everyday life (Schafersman, 1991). While the first goal is fulfilled in most universities effortlessly, the second one, however, is universities' Achilles' heel (Halpern, 2014; Bailin et al., 1999).

Fostering students' critical thinking in universities is viewed as one of the most serious challenges of today's education in the age of easy access to information. Nowadays, people are faced with an abundance of information once they turn on the radio and TV or use their social media. At the end of the day, one hardly realizes that they have received a large amount of information that may become beliefs without assessing their credibility. As university students are no exception, universities should train students on how to be able to filter the information they receive daily. However, universities seem to be far beyond fulfilling this goal. In a study that aimed to investigate the difference between the critical thinking of graduate and non-graduate students, Pithers and Soden (1991, cited in Ozmen, 2008, p. 121) concluded that there is no significant difference between the two groups. This suggests that the universities included in the study failed to instill critical thinking skills in their students.

With critical thinking being the expected outcome of higher education (Andrews, 2010; Halpern, 1998; Beyer, 1995; Lipman, 1985), students majoring in English should not be exempted from this 'educational ideal' (Siegel, 1985) simply because their major emphasizes the mastery of a foreign language. EFL learners spend a great deal of time reading, writing, and attempting to communicate in English inside or outside the classroom. Therefore, learners cannot be merely repeating or practicing the language without being critical when writing, reading or speaking in the target language. 
Given the utmost importance of the critical spirit which allows EFL learners to "question, challenge, and to demand reasons and justifications for what is being taught" (Siegel, 1985, p. 71), the present study aims to experiment the potential effects of integrating critical on students' critical thinking ability in argumentative writing.

\section{Literature Review}

\subsection{Definitions of Critical Thinking}

The attempt to investigate the potential effects of integrating critical thinking (CT) skills in a writing course on EFL learners' use of these skills in argumentative writing requires a thorough and accurate definition of critical thinking. However, a quick inspection at the available literature shows that an agreed-upon definition of CT seems to be beyond reach as theorists from different disciplines (i.e., philosophy, psychology, and education) offer a distinctive understanding of the concept (Kennedy et al., 2010; Tsui, 1998; Lewis \& Smith, 1993). As this section presents how leading theorists conceive of $\mathrm{CT}$, it foregrounds the points of similarity and difference among the various definitions.

Though he did not use the term "critical thinking", John Dewey $(1910,1925)$ was among the first philosophers who theorized about "reflective thinking" as an objective of education. Dewey defined CT as an "active, persistent, and careful consideration of any belief or supposed form of knowledge in the light of the grounds that support it and the further conclusions to which it ends" (Dewey, 1910, p. 2). His conception of CT offers a profile of a thinker who uses the available information and facts to test the validity of a statement before accepting it as a form of knowledge. This early conception of CT resonates with the objectives of contemporary education.

After paving the grounds for CT in education, Bloom et al. (1956) refined the concept of CT as an objective of education by establishing the renowned taxonomy that subsumes six categories of education objectives (i.e., knowledge, comprehension, application, analysis, synthesis, and evaluation). The three categories at the top (i.e., analysis, synthesis, and evaluation) are taken to be the skills that represent CT while the three categories at the bottom are basic skills that a thinker goes through. The power of the taxonomy is exhibited in its use as a reference for educators in developing CT curricula, assessment tests, and education goals (Reece, 2002).

Since the 1980s and 1990s, eminent attention has been given to CT as a fundamental component in philosophy and education. One of the oft-cited definitions is that of Lipman $(1988,1991)$. Lipman (1988) contends that CT is "skillful, responsible thinking that facilitates good judgment because it (1) relies upon criteria, (2) is self-correcting, and (3) is sensitive to context" (p. 39). Lipman's definition highlights 'good judgment' as the main outcome of CT that is mainly based on criteria. Similarly, Beyer argues that CT is "making reasoned judgment" (1995, p. 9).

Another definition that recurs in the literature is the one put forth by Ennis $(1993,1996)$ who defines CT as "reasonable reflective thinking focused on deciding what to believe or do" (1996, p. 166). His definition is reminiscent of Dewey's use of "reflective thinking" to describe CT. While Ennis $(1993,1996)$ and Halpern $(2014)$ use CT interchangeably with reflective thinking, decision making, problem solving, and creative thinking, Beyer (1995) draws a demarcating line between CT and these concepts.

Despite the plethora of definitions of CT, there are some aspects that could be retained about this concept. CT can be said to be an intellectual activity of reasoning that makes use of criteria and results mainly in reasonable judgments and decisions. Central to CT is skills such as analysis, synthesis, evaluation, inference etc.

\subsection{CT Skills}

The task of integrating $\mathrm{CT}$ in teaching raises the question of the skills that should be taught or introduced to students. Listing the skills of CT stems from the fact that outlining the behaviors and practices of typical critical thinkers makes the concept more teachable and more useful for educators than merely depicting the abstract characteristics of an ideal thinker (Lai, 2011; Lewis and Smith, 1993).

To start with, Ennis (2011) opts for the term CT abilities instead of CT skills. He identifies five general abilities that encompass further "skills": (1) basic clarification, (2) bases for a decision, (3) inference, (4) advanced clarification, and (5) supposition and integration. Moreover, in a panel of forty-six experts, the Delphi Report experts (Facione, 1990) asserted that CT involves (1) interpretation, (2) analysis, (3) evaluation, (4) inference, (5) explanation, and finally (6) self-regulation. It should be pointed out that the skills presented by Ennis (2011) and the Delphi report experts (Facione, 1990) subsume sub-skills.

Putting CT skills in a straightforward picture, Wade (1995) listed the following eight CT skills: (1) asking 
questions, (2) defining a problem, (3) examining evidence, (4) analyzing assumptions and biases, (5) avoiding emotional reasoning, (6) avoiding oversimplification, (7) considering interpretations, and (8) tolerating ambiguity (Malmir \& Shoorcheh, 2012). Many of these skills recur as sub-skills in the aforementioned inventories.

A closer look at the aforementioned inventories and other ones reveals that analysis, evaluation and inference are recurrent skills (Paul, 1990; Brookfield, 1987). Examining the skills that make up CT was a keystone before making decisions about the instructional treatment and assessment tools in the present experiment.

\subsection{Teaching $C T$}

\subsubsection{Approaches to Teaching CT}

The controversy about how CT skills should be taught generated four main approaches to CT instruction.

General approach refers to teaching CT skills independently of a specific subject matter. It is called so because CT skills are taught as general skills without referring to a specific context or a discipline (Ennis, 1989; Lai, 2011). The general approach to CT instruction can take two forms. It can be taught through informal logic where students are introduced to CT through abstract variables (e.g., If A, then B. A is true, therefore B). Conversely, the instructor can illustrate generalized CT skills with miscellaneous real-world (i.e. concrete) situations (Dumitru, 2013). When an instructor opts for the general approach, s/he assumes that students will transfer the skills to other domains, subjects, and non-instructional settings. This type of courses can be found in college programs which are usually labeled "critical thinking" or "informal logic", for instance.

Infusion approach suggests that students learn a subject matter besides explicit CT principles. That is, students are encouraged to think critically within the discipline they are studying. The proponents of this approach are the ones who hold a subject-specificity perspective toward CT; they claim that each discipline or subject has a peculiar logic that requires specific CT skills (Glaser, 1884; Resnick, 1987; Swartz, 1987). It should be pointed out that this is the approach that is experimented in the present study.

Immersion approach is the implicit integration of CT skills in a subject matter. That is, the instructor teaches a subject matter or a discipline where students' intellectual abilities are challenged. S/he implicitly trains students to think critically within the subject. McPeck (1981) is one of the proponents of this approach. Akin to infusion approach, immersionism entails that CT skills cannot be transferred and that each domain is characterized by its own system of thinking (Ennis, 1989).

Mixed approach is a mixture of the general approach and either the infusion or immersion approach. The instruction is twofold: while one part is devoted to the instruction of general CT skills, the other part is concerned with a subject matter loaded with CT skills (explicitly or implicitly).

The scope of the present paper does not allow a review of studies that tested the effectiveness of each of these approaches; however, it can be asserted that CT interventions through different approaches prove to be more effective in developing students' CT skills than non-interventions (Tiruneh et al., 2014; Abrami et al., 2008).

\subsection{CT in EFL Writing}

Unlike integrating $\mathrm{CT}$ in $\mathrm{L} 1$ education, embedding $\mathrm{CT}$ in $\mathrm{L} 2$ education has not always been welcomed. Atkinson (1997) maintained that adopting CT in L2 education is not feasible as it is a social practice rather than a pedagogical behavior. Despite the caution that Atkinson (1997) called for, many ESL researchers pointed out the importance of integrating CT in ESL education. Chief among these are Davidson and Dunham (1997) who argued for the integration of CT in EFL teaching; they conducted an experimental study in which they compared between two groups of 36 Japanese EFL learners; while the experimental group was taught a content-based intensive English course with CT skills, the control group received the instruction without any CT intervention (Davidson \& Dunham, 1997). The results of this study indicated that the experimental group performed better than did the control group. Hence, CT skills can be integrated in academic EFL instruction.

A decade later, a number of ESL researchers have attempted to study the impact of CT instruction on specific language skills (e.g., listening, reading, speaking, and writing). Closely related to our project study, Fahim and Mirzraii (2014) conducted an experimental study to examine the effect of dialogic CT instruction on Iranian EFL students' argumentative writing. The results of this experiment indicated that "the ability to write argumentatively crucially depends on EFL/ESL learners' being equipped with an intellectual capacity for thinking in a critical manner" (Fahim \& Mirzaii, 2014, p. 8).

In an attempt to inspect the correlation between EFL learners' argumentative writing and CT, Pei, Zheng, Zhang, and Liu (2017) administered a CT skills test and an argumentative writing test to 110 English majors across three 
grades in two Chinese universities. In order to encourage the participants' thinking, the researchers proposed a topic of writing that is culturally appropriate and familiar to Chinese students and open to discussion. The findings suggested that the correlation between the participants' CT skills and English writing proficiency is statistically insignificant. Despite these results, "textual analysis of typical essays showed that strong-CTS learners outperformed weak-CTS ones in relevance, clarity, logicality, profundity and flexibility of argumentative writing" (Pei et al., 2017, p. 31). The researchers attributed the absence of correlation to the fact that the participants came from 3 different grades which entailed 3 different proficiency levels. Interestingly, the correlation of the two same variables was found to be positive in studies of Dong and Yue (2015) and Golpour (2014) who ensured proficiency homogeneity.

In the same line of inquiry, Zeng (2012), assuming a close relationship between CT and argumentative writing, taught argumentative writing to 62 first-year university students. The instructor taught argumentative writing in addition to relevant principles of CT. Throughout the treatment which lasted four months, the participants wrote an argumentative essay every week following a six-step writing process (i.e., collecting resources, evaluating resources in group discussions, writing the first draft, peer review, revising the first draft, and post-writing feedback). Zeng (2012) found out that the participants could enhance the following CT aspects: relevance, clarity, logic, and coherence (Zeng, 2012 cited in Dong, 2015).

In the same vein, Moghaddam and Malekzadeh (2011) tested the effect of CT instruction on Iranian EFL learners' writing as well as the correlation between writing proficiency and CT ability. 70 EFL learners were asked to write about a unique topic before and after the experiment; afterwards, the participants were divided into proficient and less-proficient groups in order to examine if the level of language proficiency affects the students' CT skills in writing. Both groups received the same treatment which consisted of some principles of CT such as evaluating the evidence for alternative points of view, weighing up opposing arguments and evidence fairly, recognizing techniques for appealing etc. The results of the posttest revealed that both groups' writing improved qualitatively and quantitatively. They contended that integrating CT principles in teaching writing helps students to write more effectively. However, the results would be more insightful if the students took a CT test in order to measure the development of their CT. Furthermore, a closer inspection at the topic assigned to the participants in the pre- and posttest reveals that the CT principles taught during the treatment are not compatible with the nature of the topic assigned (i.e., you have 3 days to live, what would you do?) which could be written without any reference to $\mathrm{CT}$ principles.

The aforementioned studies experimentally tested teaching CT in contexts where the participants learn English merely as a second language, except the study conducted by Pei et al. (2017) where the participants were English majors. Hence, the present study aims to look into how the university students whose main focus is language respond to $\mathrm{CT}$ teaching in a course of writing. Moreover, the correlation suggested by the reviewed studies was taken into account when designing the present experimental study as it purports to look into the extent to which students benefit from the explicit teaching of CT on EFL learners' CT skills in argumentative writing.

\section{Statement of the Problem}

The issue that the present thesis addresses stems from two main claims. First, although universities are supposed to be the ideal place where students are trained to think critically about the knowledge they acquire, there are claims that universities fail to instill CT in their students (Halpern, 2014; Pithers and Soden, 1991). The second claim is that previous research on CT among EFL learners points that students majoring in English or a foreign language focus their attention on developing their language proficiency at the expense of developing their reasoning and thinking skills (Amrous and Nejmaoui, 2016; Belghiti, 2012). Given these claims, the present study purports to investigate the potential effect of explicitly integrating CT skills in a course of writing on EFL learners' use of CT skills in argumentative writing.

\section{Research Objectives, Questions, and Hypotheses}

The present experimental study purports:

1) To examine the extent to which EFL learners use CT skills in their argumentative essays;

2) To investigate the potential effects of integrating CT skills in teaching L2 writing on students' use of CT skills in argumentative essays.

In order to answer the foregoing objectives, two main research questions have been raised:

1) To what extent do EFL learners use CT skills in their argumentative essays? 
2) To what extent does the integration of CT skills in teaching L2 writing help students improve their CT in their argumentative essays?

Given the research objectives and questions that have been raised above, two pertinent hypotheses have been postulated:

1) The students who were taught writing in addition to CT will use more CT skills in their argumentative essays after the empirical intervention.

2) The students who were not taught $\mathrm{CT}$ will not show any significant improvement in using CT skills in their argumentative essays.

\section{Methodology}

The research design adopted in the present study is the quasi-experimental design (Campbell \& Stanely, 1963; Cohen et al., 2005). The design included a control group and an experimental group. The experimental and control groups were given the pretest and post-test in order to investigate possible causal relationship between the treatment and the results.

\subsection{Participants}

Thirty six Moroccan EFL university students served as subjects for this study. All the students were enrolled in Semester 2 taking a course of Composition in addition to other 5 courses (i.e., reading comprehension, grammar, oral communication, readings in culture, and British culture and society). The number of students $(\mathrm{N}=36)$ is evenly divided into two groups, 18 students in each group with an average age of 20.42. Belonging to the same age group and academic level, the participants in both groups had approximately the same level of proficiency in English. In order to ensure validity, the participants were randomly assigned to the groups.

At the beginning of the Semester, more than 50 students were considered as participants in the experiment but the researcher excluded a number of them for missing more than 3 classes or failing to take one of the tests. In addition, the reason behind limiting the number of participants to eighteen in each group is the researcher's concern to give all students the chance to voice their ideas and to benefit from the instructor's feedback. Since students had to review their peers' essays and share their evaluation with the whole class, it was reasonable to have a small number of students in each group.

\subsection{Treatment}

\subsubsection{Experimental Group}

With regard to the experimental group, the instructor explicitly integrated CT skills in a course of Composition. That is, the participants were taught lessons of writing together with some CT skills. Following the infusion approach where CT skills are explicitly targeted in addition to certain content knowledge, the researcher identified two types of interconnected learning aims for the course: writing learning aims and CT learning aims; the students were informed that throughout the semester they would develop their writing skills as well as their CT skills. The CT skills that were introduced to the participants center upon the elements of arguments, constructing and evaluating a thesis, detecting fallacies, evaluating arguments, evaluating evidence etc. These skills were presented in the context of argumentative writing.

\subsubsection{Control Group}

Unlike the previous group, the instructor in this group focused merely on writing skills without any reference to CT skills. The participants in the Control Group took the same writing lessons of the experimental group except that they did not receive any implicit or explicit training in CT.

\subsection{Assessment Instrument}

The argumentative essay writing test was adopted to measure the level of EFL learners' CT skills in argumentative writing. The test was administered to the participants in the two groups before (pre-test) and after (posttest) the treatment. The topic of the test differed from the pre-test to the posttest. In the pre-test, the participants in the two groups were asked to write an argumentative essay where they had to defend their position with regard to death penalty. In the posttest, the participants in the two groups were asked to compose an argumentative essay to support their positions with respect to adopting English as the language of instruction in Moroccan universities. The two topics were deliberately selected because they put students in a context where they have to argue for their position and respond to the opposing thesis, as the two issues are a subject of constant debate in Morocco (see Appendices A and B for the pretest and posttest).

The students' essays were corrected using the Illinois Critical Thinking Essay Scoring Rubric (Finken and Ennis, 
1993) so as to measure whether EFL learners were able to enhance their CT skills in argumentative writing after the treatment they received throughout the semester. For all intents and purposes, the rubric was not adopted in full. As a matter of fact, the rubric consists of six criteria which are Focus, Supporting Reasons, Reasoning, Organization, Integration, and Conventions. While the first five criteria relate to CT, Conventions, the last criterion, focuses on language proficiency (i.e., sentence construction, spelling, punctuation, paragraph format, and word usage). Therefore, the last criterion was excluded since including an aspect of language in a test of CT would provide invalid assessment about students' CT ability.

\subsection{Procedure}

The data collection of the present experimental study was carried out through three main stages. Firstly, the participants in the two groups took the pre-test, the Argumentative Essay Test. Secondly, the participants in the two groups took the writing course for one semester but under different teaching approaches. Third, immediately after the end of the course, the students took the post-test, the Argumentative Essay Test.

\section{Results}

In order to investigate the potential effect that integrating CT skills has on students' CT ability in argumentative writing, the researcher administered an argumentative essay pre-test and posttest to the experimental group and control group. The participants' essays were blindly and carefully scored by the researcher using the Illinois Critical Thinking Essay Scoring Rubric (Finken and Ennis, 1993). The participants' scores were processed through the Paired Samples t-test in order to test the aforementioned hypotheses.

\subsection{Sample Characteristics}

Before testing the two hypotheses, it is worth looking at the descriptive statistics. Tables (1) and (2) present the distribution of the means and standard deviations among the experimental group and control group in the pretest and posttest, respectively.

Table 1. Pre-test Scores

\begin{tabular}{lll}
\hline Groups & Mean & Standard Deviation \\
\hline Experimental Group & 13.11 & 3.96 \\
Control Group & 10.72 & 2.56 \\
\hline
\end{tabular}

In the pretest, the participants in the Experimental Group obtained a mean score of (13.11) while the Control Group scored a mean of (10.72), with a difference of only (2.39). The small difference between the means obtained by the two entails that the participants exhibit almost similar CT skills in argumentative writing before the beginning of the instructional treatment. With regard to the variability of the data from the point of central tendency, the standard deviation of the experimental group $(\mathrm{SD}=3.96)$ and the control group $(\mathrm{SD}=2.56)$ is fairly small indicating that the scores among the participants are tightly clustered around the mean.

A quick look at the means of the two groups indicates that the level of the use of CT skills in argumentative writing is relatively low as the two groups were not able to reach the average $(=15)$ in CT ability in argumentative writing.

Table 2. Posttest scores

\begin{tabular}{lll}
\hline Groups & Mean & Standard Deviation \\
\hline Experimental Group & 18.83 & 3.46 \\
Control Group & 11.33 & 3.37 \\
\hline
\end{tabular}

In the posttest, the experimental group obtained a mean score of (18.83) which is higher than the one scored in the pre-test. As far as the control group's performance in the posttest is concerned, the participants obtained a mean of (11.33) which is only (.61) higher than the mean scored in the pretest.

Determining whether the differences between the means scored in the pretest and posttest is statistically significant requires the examination of the inferential statistics obtained via the operation of the Paired Samples t-test. 


\subsection{Normality Assumption}

Prior to running the Paired Samples t-test, examining the assumption of normal distribution is crucial.

Table 3. Normality tests

\begin{tabular}{llll}
\hline & Groups & Skewness & Kurtosis \\
\hline Pretest & Experimental Group & -.63 & -.24 \\
& Control Group & .54 & -.98 \\
Posttest & Experimental Group & -.20 & -1.09 \\
& Control Group & .11 & -.21 \\
\hline
\end{tabular}

It can be asserted that the assumption of normal distribution is satisfied as the Skewness and Kurtosis levels are less than the maximum allowable values for a t-test (i.e., Skewness $<|2|$ and Kurtosis $|9.0|$; Posten, 1984). Accordingly, the results of the Paired Samples t-test can be taken into account as the scores are normally distributed throughout the four observations.

\subsection{The Effect of CT Instruction on EFL Learners' CT in Argumentative Writing}

Table 4. Paired Samples Correlations

\begin{tabular}{lll}
\hline Groups & Correlation & Sig. \\
\hline Experimental Group (pre-to-posttest) & .719 & .000 \\
Control Group (pre-to-posttest) & .793 & .000 \\
\hline
\end{tabular}

Before looking at the significance level, it should be pointed out that the correlation between the pre-test and posttest scores in both groups was estimated at $r(.71)$ and (.79) that are extremely significant at (.00) and (.00), respectively. This correlation suggests that the participants tend to have the same ranking in the pre-test and posttest; higher scores in the pre-test were associated with higher scores in the posttest and vice versa.

The scores of the experimental group participants from the pre-test to the posttest point to a t-value (-8.59) that is extremely significant at $(.00)$. Therefore, the mean of the posttest is statistically higher than the pretest mean. Thus, Hypothesis (1) is confirmed.

Table 5. Paired-samples t-test on EG's Pretest and Posttest

\begin{tabular}{lllllll}
\hline Experimental Group & from & Mean & SD & T & Df & Sig. (2-tailed) \\
\cline { 2 - 6 } Pretest to Posttest & $-5,72$ & 2.82 & -8.59 & 17 & .000 \\
\hline
\end{tabular}

$\mathrm{p}<.05$.

The scores of the control group participants from the pre-test to the posttest indicate to a t-value $(-1.25)$ that is extremely insignificant at (.22). Since the mean of the posttest is not statistically higher than the mean of the pretest, Hypothesis 2 is confirmed.

Table 6. Paired-samples t-test on CG's Pretest and Posttest

\begin{tabular}{llllll}
\hline $\begin{array}{l}\text { Control Group from Pretest } \\
\text { to Posttest }\end{array}$ & Mean & SD & T & Df & Sig. (2-tailed) \\
\cline { 2 - 6 } & -.61 & 2.06 & -1.25 & 17 & .225 \\
\hline
\end{tabular}

$\mathrm{p}<.05$.

These results suggest that integrating CT skills in teaching writing to EFL learners helps students develop their $\mathrm{CT}$ ability in argumentative writing as the students who benefited from an infusion approach to teaching $\mathrm{CT}$ in 
writing significantly outperformed the students who were taught writing without any reference to CT skills.

\section{Analysis and Discussion}

\subsection{The State of Affairs of CT Skills in Argumentative Writing among EFL Learners}

The means reported above suggest insights into the status quo of Moroccan EFL learners' CT ability in argumentative writing. Their level is relatively low as the participants' scores in the pretest did not reach the average.

Though the sample is too small to make generalizations about Moroccan undergraduate EFL learners, this finding is in accord with other studies which measured the CT ability of first-year students majoring in English (Amrous \& Nejmaoui, 2016; Pei et al., 2017). In their developmental account of CT in argumentative writing across three different academic levels, Amrous and Nejmaoui (2016) concluded that Moroccan Semester-Two students majoring in English do not make use of sufficient CT skills in argumentative writing. Similarly, the findings shared by Pei et al. (2017) indicate that the level of CT skills among Chinese students majoring in English is low. The low level of CT skills among undergraduates majoring in English, be they Moroccans or Chinese, can be attributed to the focus of the programs in the departments of English on language proficiency.

For instance, a look at the courses offered to Moroccan students at the departments of English in the first year could explain this finding; most of the departments of English offer courses (e.g., grammar, composition, vocabulary, reading comprehension, oral communication, study skills etc.) whose learning objective is to develop learners' proficiency in English. With courses that concentrate on language proficiency and overlook reasoning and thinking skills, a low level of CT competence among language learners seems to be a plausible outcome (Moghaddam \& Malekzadeh, 2011; Arju, 2010). Hence, the integration of CT skills in courses such as composition and reading becomes mandatory.

The present study may suggest a portrait of EFL learners' CT ability in argumentative writing, but it cannot provide any information about their CT ability in a general context as it did not measure this skill using a standard test of CT (e.g., Watson-Glaser Critical Thinking Appraisal Test, Cornell Critical Thinking Test, California Critical Thinking Skills Test etc.). A more overarching study would have to measure students' CT skills in a general context, in argumentative writing, and other contexts to see if there are any discrepancies between their performances in different contexts.

\subsection{Lack of Progress in the Absence of CT Instruction}

The absence of improvement in the CT ability of the participants in the control group is supported by previous studies whose investigations assert the mandatory instruction of CT and the correlation between learners' CT ability and argumentative writing.

The fact that the participants in the control group did not show any improvement in their CT skills after a course of composition is corroborated by the contention that students' CT competence is not developed unless taught (Halpern, 2014; Gelder, 2005). In this regard, Gelder (2005) contends that "humans are not naturally critical" (p.42); that is, if students are not taught how to weigh the evidence, think about alternative hypotheses, raise pertinent questions, check the credibility of sources, and other skills, they are inclined to take claims and beliefs for granted. Likewise, Halpern (2014) compared teaching CT skills to teaching basic skills such as writing or calculating. Thus, the absence of CT skills, objectives, and activities in courses in general, and language courses in particular, raises the alarm about university students' basic rights to benefit from an education where reasoning and thinking skills are facilitated.

Empirical evidence lends weight to the finding of the present study. Bangert-Drowns and Bankert (1990) analyzed 20 studies which tested the effectiveness of the explicit instruction of CT. Their analysis confirmed that the students in the control groups always underperformed in CT tests. Hence, one cannot but assert that CT cannot be nurtured in EFL learners unless it is taught to them. Nevertheless, all the studies reviewed by Bangert-Drowns and Bankert (1990) integrated CT in content courses where English is the students' first language. A review of the outcomes of studies conducted in ESL contexts would give more credibility to the claims being put forth in the present study.

Finally, the absence of a significant improvement as a result of overlooking the integration of CT skills in teaching argumentative writing relates to a correlation between CT and argumentative writing, a claim defended by recent studies about CT in L2 writing (Dong \& Yue, 2015; Qian, 2015; Golpour, 2014). These studies measured students' CT ability and argumentative writing proficiency separately and found out that the two abilities correlate; while strong critical thinkers are better writers, weak critical thinkers are weak writers. Though it should be pointed out that argumentative writing does not automatically stand for CT or vice versa, CT 
skills are fundamental to a good piece of argumentative writing (Çavdar \& Doe, 2012; Bean, 2011). In other words, constructing a valid argument, evaluating an alternative thesis, detecting the credibility of sources, and assessing the relevance of evidence are skills commonly essential to CT and argumentative writing. Accordingly, disregarding CT in teaching L2 writing is more likely to help students compose essays that are grammatically and lexically accurate but lack the skills required to make a valid argument.

\subsection{The Integration of CT in L2 Writing}

The significant improvement in the use of CT skills in argumentative writing that the experimental group exhibited after the treatment contributes to the acclaimed effectiveness of the explicit approach to CT.

The students' ability to use clearer and more credible evidence, address alternative positions and arguments, support conclusions, and maintain the logical flow of ideas in their essays did not reach a mastery level in the posttest, yet the average level they reached is reassuring in view of the short time of the training they had. An integration of $\mathrm{CT}$ in courses of writing over the coming semesters may bring forth encouraging outcomes.

The positive results generated through integrating CT in this study contribute to the debate over teaching CT in L2 education. The present study besides other experimental studies (Fahim \& Mizraii, 2014; Zeng, 2012; Moghaddam \& Malekzadeh, 2011; Stapleton, 2001; Davidson \& Dunham, 1997 etc.) substantiate the possibility of introducing CT in L2 despite Atkison's (1997) claim that CT is a Western social practice. As a matter of fact, EFL learners in the present experiment as well as in the foregoing experiments managed to use reasoning skills to argue more critically in their essays.

When compared to teaching conditions where CT is not introduced, the explicit teaching of CT skills seems to lead to more fruitful results according to systematic reviews of empirical studies (Tiruneh et al., 2014; Behar-Horenstein \& Nie, 2011; Abrami et al., 2008; Banger-Drowns \& Bankert, 1990). Nevertheless, the explicit approach to teaching CT displayed moderate effects in comparison to the mixed approach which is taken to be the most effective at strengthening students' general CT skills and facilitating their application of these skills to a specific domain of knowledge (Tiruneh et al., 2014; Abrami et al., 2008; Solon, 2007). It is noteworthy that the reviewed experiments tested the explicit approach and mixed approach in content courses; further research is, therefore, required to experiment these approaches in ELT contexts.

\section{Conclusion}

The results of this study, as well as other studies, propound that the absence of CT skills from language courses entails that the learners who are deprived from the opportunity to learn how to think critically (e.g., learners in the control groups) tend to perform less than the ones who benefit from CT instruction. Conversely, the integration of CT is bound to guide students to think more critically about the information they receive, check the credibility of sources, attempt to consider alternative theses, evaluate evidence etc. The moderate positive results attained from the integration of CT in writing for only a semester promise more positive outcomes if CT is integrated in L2 writing courses for longer periods. Considerations of transferability of these skills from writing to other courses, reading for instance, are essential to examine if students would be able to transfer these skills across the curriculum.

Another conclusion that the present study suggests is that CT is teachable in L2 classes. However, the number of studies which experiment different approaches and techniques to facilitate CT in L2 education are limited. More studies are required in this field. In addition, the CT tests used in these studies to measure students' CT ability were designed for native speakers in the first place; hence, designing tests appropriate for EFL learners will ensure the validity of CT assessment in this area.

The findings of the present study suggest a number of implications for English language educators teaching students majoring in English. Though these educators may object to integrating CT in their syllabi due to the fact that their focus should be on language purposes, striking a balance between CT and language is bound to enable EFL university students to develop their thinking skills. EFL educators are, therefore, invited to set CT as a learning aim besides language. When CT is set as a learning aim, teachers can integrate it through Socratic questioning, argument mapping, self-assessment, multi-drafting etc. Finally, the interconnection between CT and argumentative writing invites theorists and instructors of L2 writing to consider designing syllabi and teaching materials that intrinsically aim to develop CT and writing simultaneously.

\section{References}

Abrami, P. C., Bernard, R. M., Borokhovski, E., Wade, A., Michael, A., Surkes, R., \& Zhang, D. (2008). Instructional interventions affecting critical thinking skills and dispositions: A stage 1 meta-analysis. Review of Educational Research, 78(4), 1102-1134. https://doi.org/10.3102/0034654308326084 
Andrews, R. (2010). Argumentation in Higher Education: Improving Practice through Theory and Research. New York: Routledge. https://doi.org/10.1007/s10503-009-9176-5

Amrous, N., \& Nejmaoui, N. (2016). A Developmental Approach to the Use of Critical Thinking Skills in Writing: The Case of Moroccan EFL University Students. Arab World English Journal, ASELS Annual Conference Proceedings, 142-156.

Arju, S. (2010). Proposing opinion writing as a practice of critical thinking. The Reading Matrix, 10(1), $106-114$.

Atkinson, D. (1997). A critical approach to critical thinking in TESOL. TESOL Quarterly, 31(1), 71-94. https://doi.org/10.2307/3587975

Bangert-Drowns, R L., \& Bankert, E. (1990). Meta-Analysis of effects of explicit instruction for critical thinking. Paper presented at the Annual Meeting of the American Educational Research Association Boston, MA.

Bean, J. C. (2011). Engaging ideas: The professor's guide to integrating writing, critical thinking, and active learning in the classroom (2nd ed.). San Francisco, CA: Jossey-Bass.

Behar-Horenstein, L. S., \& Niu, L. (2011). Teaching critical thinking skills in higher education: A review of the literature. Journal of College Teaching \& Learning, 8(2), 25-42. https://doi.org/10.19030/tlc.v8i2.3554

Belghiti, K. (2012). Critical Thinking Skills in Reading and Writing: The Case of Moroccan EFL University Students (Unpublished Doctoral Dissertation). Mohammed V University, Rabat.

Beyer, B. K. (1995). Critical Thinking. Bloomington, Indiana: The Phi Delta Kappa Educational Foundation.

Bloom, B. S., Engelhart, M. D., Furst, E. J., Hill, W. H., \& Krathwohl, D. R. (1956). Taxonomy of educational objectives: the classification of educational goals; Handbook I: Cognitive Domain. New York: Longmans.

Brookfield, S. D. (1987). Developing Critical Thinkers: Challenging Adults to Explore Alternative Ways of Thinking and Acting. San Francisco: JosseyBass.

Campbell, D. T., \& Stanely, J. C. (1966). Experimental and Quasi-Experimental Designs for Research. Boston: Houghton Mifflin Company.

Çavdar, G., \& Doe, S. (2012). Learning through writing: Teaching critical thinking skills in writing assignments. PS: Political Science and Politics, 45(2), 298-306. https://doi.org/10.1017/S1049096511002137

Cohen, L., Manion, L., \& Morison, K. (2005). Research Methods in Education. Taylor \& Francis e-Library.

Davidson, B., \& Dunham, R. (1997). Assessing EFL student progress in critical thinking with the Ennis-Weir Critical Thinking Essay Test. JALT Journal, 19, 43-57.

Dewey, J. (1910). How We Think. Boston: D.C Heath \& Co. https://doi.org/10.1037/10903-000

Dewey, J. (1991). Experience and Education. In J. A. Boydston (Ed.), The Later Works of John Dewey 1925-1953 (pp. 271-292). Southern Illinois: University Press.

Dong, T., \& Yue, L. (2015). A Study on critical thinking assessment system of college English writing. English Language Teaching, 8(11), 176-182. https://doi.org/10.5539/elt.v8n11p176

Dong, Y. (2015). Critical Thinking in Second Language Writing: Concept, Theory and Pedagogy. (Unpublished Doctoral Dissertation). The University of British Columbian, Vancouver.

Dumitru, D. (2013). The transfer and the transferability of critical thinking skills. Transylvanian Review, 22(3), 141-148.

Ennis, R., (1989). Critical thinking and subject specificity: Clarification and needed research. Educational Researcher, 18(3), 4-10.

Ennis, R. H. (1993). Critical thinking assessment. Theory into Practice, 32(3), 179-186. https://doi.org/10.1080/0 0405849309543594

Ennis, R. H. (1996). Critical Thinking Dispositions: Their Nature and Assessability. Informal Logic, 18(2 \& 3), 165-182. https://doi.org/10.22329/il.v18i2.2378

Ennis, R. H. (2011). The Nature of Critical Thinking: An Outline of Critical Thinking Dispositions and Abilities. Retrieved June 21, 2017, from http://faculty.education.illinois.edu/rhennis/documents/TheNatureofCritical Thinking_51711_000.pdf

Facione, P. A. (1990). Critical thinking: A Statement of Expert Consensus for Purposes of Educational Assessment and Instruction. Millbrae, CA: The California Academic Press. 
Fahim, M., \& Mizraii, M. (2014). Improving EFL argumentative writing: A dialogic critical thinking approach. International Journal of Research Studies in Language Learning, 3(1), 3-20.

Finken, M. M. (1992). Guidelines for Scoring Illinois Critical Thinking Essay Tests. Retrieved May 31, 2015, from http://www.criticalthinking.net/IllCTEssayTestFinken-Ennis12-1993LowR.pdf

Halpern, D. (2014). Thought and knowledge: An introduction to critical thinking. New York: Psychology Press.

Gelder, T. V. (2005). Teaching critical thinking: Some lessons from cognitive science. College Teaching, 53(1), 41-46. https://doi.org/10.3200/CTCH.53.1.41-48

Golpour, F. (2014). Critical thinking and EFL learners' performance on different writing modes. Journal of Pan-Pacific Association of Applied Linguistics, 18(1), 103-119.

Halpern, D. F. (1998). Teaching for critical thinking: Helping college students develop the skills and dispositions of a critical thinker. New Directions for Teaching and Learning, 1999(88), 69-74.

Kennedy, M., Fisher, M. B., \& Ennis, R. H. (1991). Critical thinking: Literature review and needed research. In L. Idol \& B. F. Jones (Eds.).

Kothari, C. R. (2004). Research methodology-methods and techniques. New Delhi: New Age International (P) Ltd.

Lai, R. E. (June 2011). Critical thinking: A literature review. Retrieved April 13, 2015, from http://images.pearso nassessments.com/images/tmrs/CriticalThinkingReviewFINALpdf

Lewis, A., \& Smith, D. (1993). Defining higher order thinking. Theory into Practice, 32(3), 131-137. https://doi.org/10.1080/00405849309543588

Lipman, M. (1985). Thinking skills fostered by philosophy for children. In J. W. Segal (Ed.), Thinking and Learning Skills: Relating Instruction to Research (pp. 83-108). Hillsdale, NJ: Earlbaum. https://doi.org/10. 5840/thinking 1985547

Lipman, M. (1988). Critical thinking: What can it be? Educational Leadership, 46(1), 38-43.

Lipman, M., (1991). Thinking in Education, Cambridge University Press.

Malmir, A., \& Shoorcheh, S. (2012). An investigation of the impact of teaching critical thinking on the Iranian EFL learners' speaking skill. Journal of Language Teaching and Research, 3(4), 608-617. https://doi.org/ 10.4304/jltr.3.4.608-617

McPeck, J. (1981). Critical Thinking and Education. Don Mills: Oxford University Press.

Moghaddam, M. M., \& Malekzadeh, S. (2011). Improving L2 writing ability in the light of critical thinking. Theory and Practice in Language Studies, 1(7), 789-797. https://doi.org/10.4304/tpls.1.7.789-797

Ozmen, S. K. (2008). Current state and understanding of critical thinking in higher education. Gazi Eğitim Fakültesi Dergisi, 28(2), 109-127.

Paul, R. (1990). Critical Thinking: What Every Person Needs to Survive in a Rapidly Changing World. In A. J. A. Binker (Ed.). Robert Park, CA: Center for Critical Thinking and Moral Critique.

Pei, Z., Zheng, C., Zhang, M., \& Liu, F. (2017). Critical thinking and argumentative writing: Inspecting the association among EFL learners in China. English Language Teaching, 10(10), 31-42. https://doi.org/10.5 539/elt.v10n10p31

Posten, H. O. (1984). "Robustness of the two-sample t-test," in Robustness of Statistical Methods and Nonparametric Statistics. In D. Rasch, \& M. L. Tiku (Eds.). (Dordrecht: Springer Netherlands), 92-99.

Qian, J. (2015). A study of critical thinking's impact on English majors' argumentative writing. (Unpublished thesis) Central China Normal University, Wuhan, China.

Reece, G. (2002). Critical thinking and transferability: A review of the literature. Retrieved July 20, 2017, from http://people.umass.edu/curtis/academics/researchtoolbox/pdfs/Reece_LitReview_2010.pdf

Resnick, L. B. (1987). Education and Learning to Think. Washington DC: National Academy Press.

Schafersaman, S. D. (1991). An introduction to critical thinking. Retrieved December 31, 2017, from http://facultycenter.ischool.syr.edu/wp-content/uploads/2012/02/ Critical-Thinking.pdf

Siegel, H. (1985). Educating reason: Critical thinking, informal logic, and the philosophy of education. Informal Logic, 7(2), 69-81. https://doi.org/10.22329/il.v7i2.2706 
Solon, T. (2007). General critical thinking infusion and course content learning in introductory Psychology. The Journal of Instructional Psychology, 34(2), 95-109.

Swartz, A. (1987). Teaching for Thinking: A Developmental Model for the Infusion of Thinking Skills into Mainstream Instruction. In J. Baron, \& R. Sternberg (Eds.), Teaching Thinking Skills: Theory and Practice, (pp. 106-126). New York: W. H. Freeman \& Co.

Tiruneh, D. T., Verburgh, A., \& Elen, J. (2014). Effectiveness of critical thinking Instruction in higher education: A systemic review of intervention studies. Higher Education Studies, 4(1), 1-17. https://doi.org/10.5539/hes. $\mathrm{v} 4 \mathrm{n} 1 \mathrm{p} 1$

Tsui, L. (1998). A review of research on critical thinking. ASHE Annual Meeting Paper. (ERIC Document Reproduction Service No. ED427572).

Wade, C. (1995). Using writing to develop and assess critical thinking. Teaching of Psychology, 22(1), 24-28. https://doi.org/10.1207/s15328023top2201_8

Zeng, M. R. (2012). Argumentative writing and the cultivation of critical thinking ability. Education Teaching Forum, 23, 67-70.

\section{Appendix A}

\section{Argumentative Essay Pretest}

Death penalty is one of the most controversial issues that still divide people's opinions. While some believe that death penalty is a punishment that violates human rights, others believe that death penalty is the fairest punishment that dangerous criminals can get.

Write an argumentative essay, in which you defend your opinion with specific reasons and examples that support your point of view. You are given 90 minutes.

\section{Appendix B}

\section{Argumentative Essay Posttest}

Although French is still dominant in many domains in Morocco, a number of political bodies and researchers have called for adopting English as the language of instruction in Moroccan universities. What do you think of this opinion?

Write a short argumentative essay, in which you defend your opinion with specific reasons and examples that support your point of view. You are given 90 minutes.

\section{Copyrights}

Copyright for this article is retained by the author(s), with first publication rights granted to the journal.

This is an open-access article distributed under the terms and conditions of the Creative Commons Attribution license (http://creativecommons.org/licenses/by/4.0/). 